Peter Vinzenz Bartl

\title{
The Upper Tigris - Cultural Autonomy or Interdependence? The Case of Ziyaret Tepe and Giricano
}

\section{o. Introduction}

Following the decision of the Turkish government to build the Ilisu and Carchemish Dam reservoirs along the Euphrates and Tigris Rivers, an agreement was reached in 1998 between the Middle East Technical University's Centre for Research and Assessment of the Historic Environment (TAÇDAM), the Ministry of Culture, and the State Hydraulic Works (D.S.I..). This agreement allowed numerous research projects and excavations to take place in the upper Tigris region in Diyarbakır Province of southeastern Turkey. Before the agreement, this region was little known and its importance was seen as modest, but it has now attracted the attention of the international scientific community, ${ }^{\mathrm{I}}$ as it played a decisive role in the cultural history of northern Mesopotamia. It features a unique landscape between the modern cities of Diyarbakır and Siirt, forming a geographically closed settlement area within the upper Mesopotamian piedmont.

The previous gap in our archaeological knowledge of the region is steadily being filled by recent or ongoing investigations at sites such as Üçtepe, Ziyaret Tepe, Giricano, Salat Tepe, Kavuşan Höyük, Hirbemerdon Tepe, and many others. ${ }^{2}$ Archaeological data from these excavations make an important contribution to the definition and understanding of these settlements' material culture and the role they have played in shaping the region during the periods investigated. The results obtained so far show that, at certain periods in time, influence from Mesopotamia was predominant, whereas in other periods the region was more independent, or more closely connected to the northern and eastern highlands. Periods of dependence on Mesopotamia include the early Early Bronze Age, the Mittanian and Middle Assyrian periods, and the Late Assyrian period. By contrast in the late Early Bronze Age and Middle Bronze Age - from the late third through the first half of the second millennium - local cultures thrived in the upper Tigris valley, while in the Early Iron Age after the collapse of the Middle Assyrian empire the area was culturally connected to the adjacent mountainous regions.

From the new investigations the picture emerges of a relatively autonomous cultural development in the Middle Bronze Age with few connections to either the upper Khabur region to the south or the nomadic or semi-nomadic cultures of the uplands to the north and northeast. 3

The local material culture is characterized by a specific pottery tradition of, in the main, so-called Red Brown Wash Ware.4 Another characteristic is the presence of extensive, probably multifunctional

I A short summary of the history of research into this region before the ongoing rescue excavations can be found in Radner / Schachner 200I, 753-754.

2 For a detailed presentation of the recent and ongoing excavations in the area: Tuna / Öztürk I999; Tuna et al. 200I; Tuna / Velibeyoğlu 2002; Tuna et al. 2004. The homepage of the Middle East Technical University provides some information on the region and its sites up to
2002, when it was last updated: <http://tacdam.metu. edu.tr/tacdam> (accessed 20II-O2-OI). Özfirat 200I; Ur / Hammer 2009.

4 The role and characteristics of the Middle Bronze Age pottery assemblage has been the subject of considerable debate. This will be revisited in the presentation of the material evidence. For the sake of simplicity this pottery shall henceforth be termed RBWW. 
building complexes such as those found in Giricano and Salat Tepe, which probably represent agricultural production centers, similar to those known from texts from Mittanian Nuzi (dimtu) and from Middle Assyrian sources (dunnu), 5 one of which is attested at Giricano (Dunnu-ša-Uzibi) (Radner 2004).

The aim of this paper is to present the results from the excavations in Giricano and Ziyaret Tepe in order to investigate some issues concerning the natural environment and its relationship to the local human societies and their economic and political development. ${ }^{6}$

\section{Local geography and topography}

The region discussed can easily be identified from satellite images7 or topographic maps. It is characterized by a fertile plain bordered by the high mountain ranges of the Taurus to the north and the Tur Abdin (Mardin Dağları) to the south. ${ }^{8}$ To the west the border is defined by the cone-shaped mountain Karacadağ, an extinct volcano, while the eastern border can be set in the Siirt region, where the Tigris River turns south and the valley becomes a gorge.

The Tigris, which traverses the region from west to east, flows through a deep gorge until it emerges from the mountains about $20 \mathrm{~km}$ north of Diyarbakır. $8 \mathrm{~km}$ further downstream from that city, the course of the river turns eastwards, cutting several river terraces in the fertile plain (Kuzucuoğlu 2002; Doğan 2005). On both sides of the river a gradually ascending, low-relief terrain, which is subject to erosion and cut by seasonal streams and tributaries draining to the Tigris, extends both to the northern mountain ranges at a distance of $35-45 \mathrm{~km}$ and to the southern ranges about $15-20 \mathrm{~km}$ away.

The fertile plain along both banks of the river is now used for cultivation and agricultural activities, as it probably was in antiquity. East of the Batman-Tigris confluence, this gives way to a very different kind of landscape, mainly consisting of eroding uplands. Between the limits of the Raman Dağı mountain range to the north and high plateaus of uneven terrain to the south, only a small strip of floodplain and of narrow river terraces is left available for agricultural activities on each side of the main stream and its tributaries, along with isolated pockets of debris accumulation (e.g., around Hasankeyf, east of Batman along the Garzan Çay, and north of Savur in the central Tur Abdin). The surrounding hinterland consists of a mountainous landscape of rough terrain. High hills with partially exposed bedrock and seasonal wadis formed by centuries of erosion shape the landscape. This terrain extends to the Siirt region, where the Tigris River turns south again and cuts its way through the mountain ranges towards the

5 See Wiggermann 2000, I72-I74 with older literature; Koliński 200I, 3-2I; Radner 2004, 70-7I.

6 I am greatly indebted to Michael Roaf and Andreas Schachner for their ongoing support of my research. As this is part of my Ph.D. research, in this paper I would like to raise questions and hypotheses about some of the issues presented. The in-depth analysis of the data is still ongoing and hence incontrovertible results are not to be expected at this point, yet some central issues can be addressed and discussed as far as is possible without anticipating future developments. I would like to thank the editor for giving me the opportunity to present my research within the scope of the piedmont workshop. Any errors remain the author's responsibility.

7 The Landsat and ASTER datasets and that from the CORONA satellite, which was declassified in I995, have been used extensively in a variety of landscape studies (Ur 2003; Wilkinson et al. 2005). However, Google Earth presents an equally useful tool for analyzing landscapes and settlement patterns as long as suitable high resolution datasets are available.

8 For a general introduction to the topography, see e.g., Hütteroth I982, fig. 26. A detailed description of the area is also provided by Andrew Palmer (Palmer I990, I07-109). Research on the geoarchaeological development of the upper Tigris valley has been conducted by Catherine Kuzucuoğlu and Uğur Doğan (Kuzucuoğlu 2002; Doğan 2005). Further research by Kathleen Nicoll and Timothy Demko was conducted within the scope of the Ziyaret Tepe Archaeological Project (Matney et al. 2003, 200-202; Matney / Rainville 2005, 42-44). An in-depth analysis was presented recently in Nicoll 20I0a, 20I0b. 


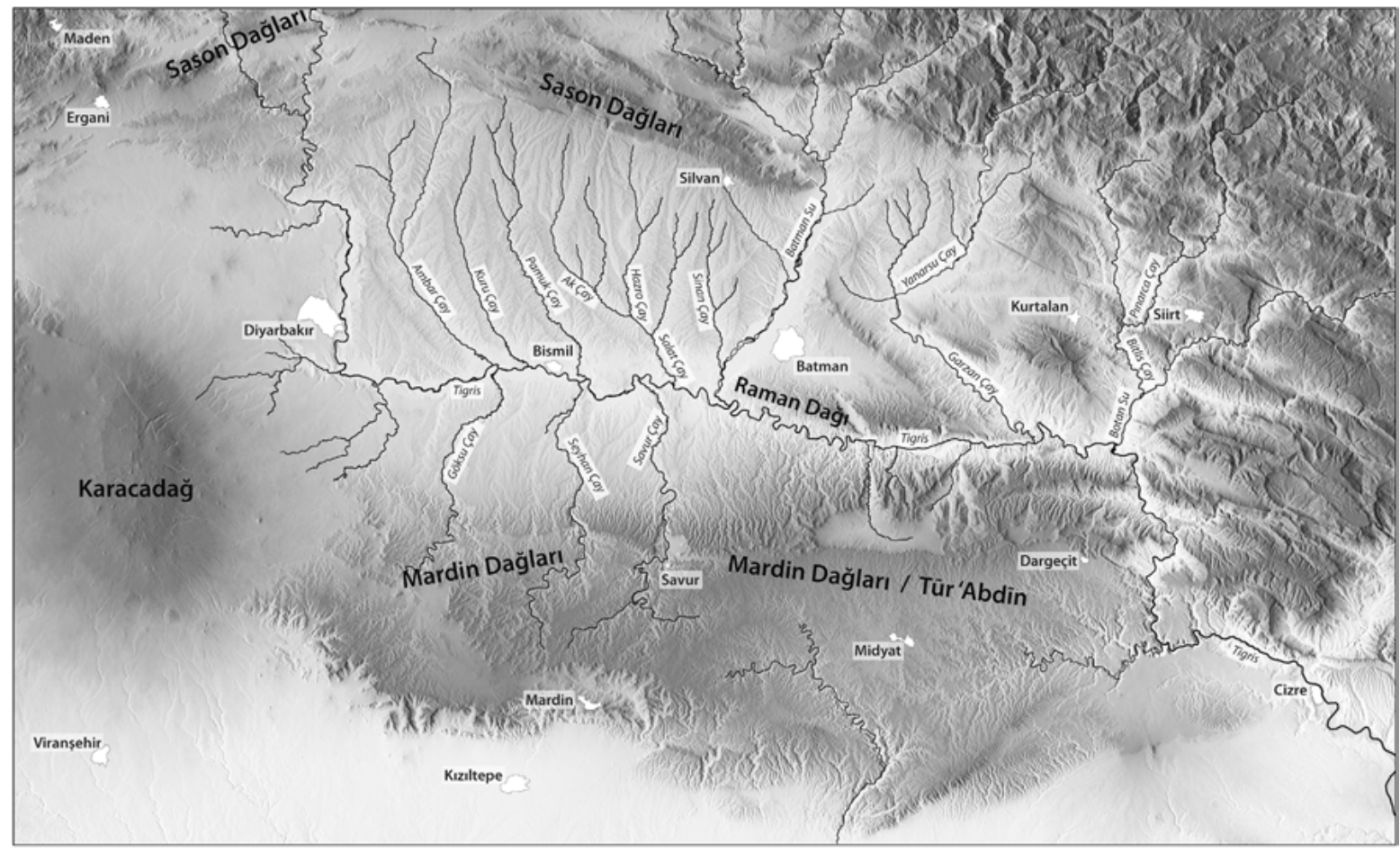

Fig. 1 | Topographic map of the region with shaded relief. A detail of the map below shows the location of known Middle Bronze Age sites (modern towns are hatched).

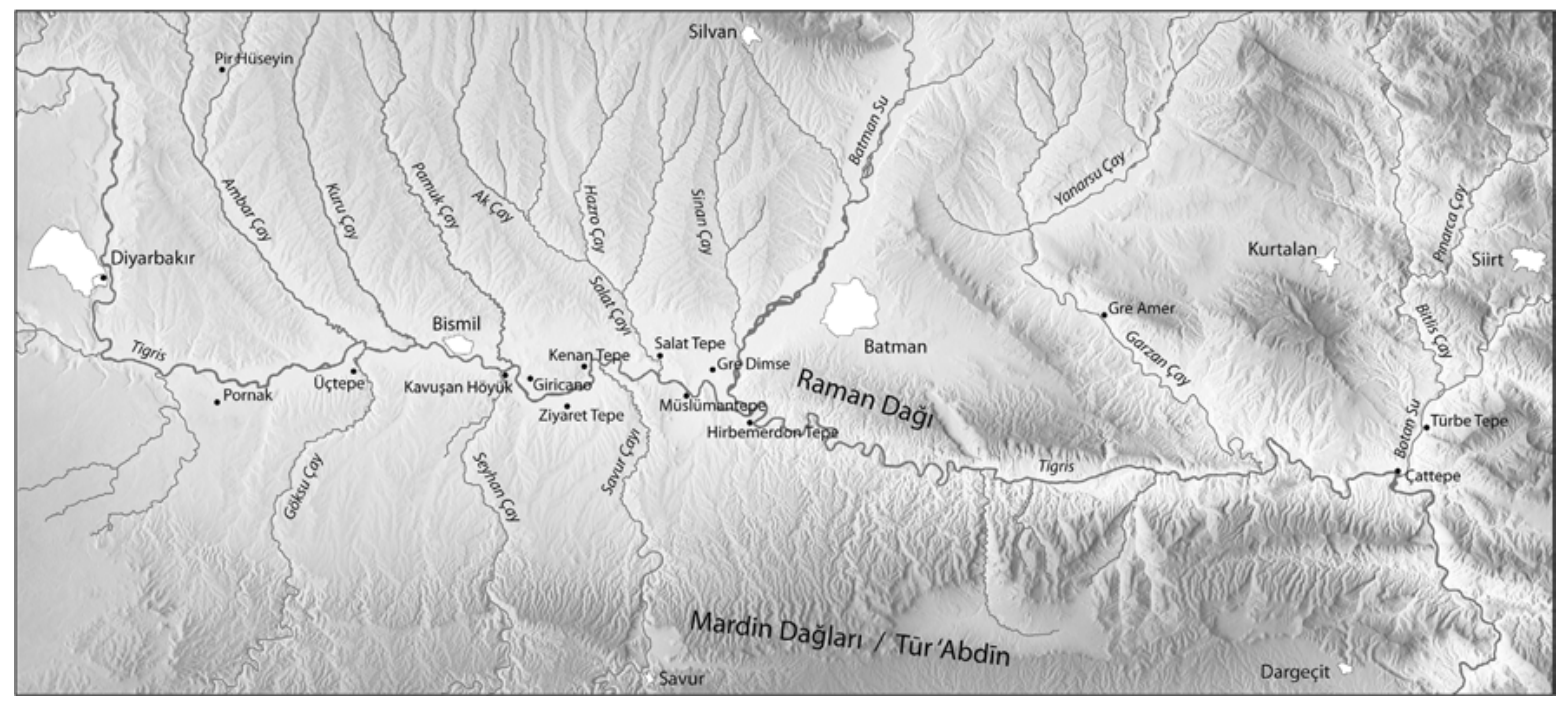

Fig. 2 | Map showing location of sites discussed in the text (black dots) and of modern towns (hatched). 
Cizre plain. Today this region is predominantly used for animal husbandry, as it probably was in antiquity. 9

This dichotomy in the region's topography, and thus in its accessibility and economic usability, not only shapes the modern land-use but also suggests that a similar pattern existed in antiquity, resulting in a diversity of agricultural practices. Moreover we should also bear in mind that a different kind of vegetation was present in antiquity, which has now almost totally vanished ${ }^{\text {io }}$ and given way to irrigated fields and cotton plantations: open woodland of scattered oaks and pistachios providing sufficient habitat for deer and other wild animals, whose bones have been excavated on several sites. ${ }^{\text {II }}$

This diversity is also represented in the botanical samples retrieved: huge amounts of carbonated bulk crops such as barley and emmer are present, as are legumes and grapes. ${ }^{22}$ The role of the vine in the economy of Assyrian times (Radner 2006, 286) should not be neglected; vines are still cultivated today in the Tur Abdin mountains, where they provide the local communities with wine and grapes.

The area lies within the semi-arid climatic zone of southeastern Turkey, north of the $250 \mathrm{~mm}$ isohyet required for rain-fed agriculture (annual precipitation ranges from 500 to $600 \mathrm{~mm}$ ). Yet it is possible that irrigation systems were used in some areas to increase the variety and abundance of crops cultivated. ${ }^{13}$ In other areas, particularly in the reach of the Tigris east of Bismil, where the river meanders in a wide alluvial valley, numerous karstic depressions such as ponds, sinkholes, and dolines and an elevated groundwater table provide an abundance of water and even transform parts of the land into swampland when no efficient water management is provided (Nicoll 20IOa, 4I7-4I8, fig. 8; 20Iob, fig. 5).

The division of the region into different environmental zones used for cultivation and for pastoralism raises the question of suitable land for settlements. Usually one would consider survey methods, the landscape, and the general visibility and character of archaeological sites, yet this cannot be done at this point. For the moment, potential areas can be highlighted: geoarchaeological and geomorphological research has provided insight into the Quarternary development of the riverbed and land subsidence and into Holocene environmental changes. For the area between Bismil and Batman it has been demonstrated that from the Early Bronze Age to the Iron Age there was a period of prolonged sedimentation and recurring river flooding in an incising and meandering fluvial environment, making the floodplains almost uninhabitable (Kuzucuoğlu 2002; Doğan 2005, table I-2, 84). The archaeological data corroborate these results, as some of the settlements on the lower terrace were partly eroded (Müslümantepe, Kavuşan Höyük), and Chalcolithic and Early Bronze Age levels were covered by silt bands (Aşağ Salat Tepe, Kavuşan Höyük, Hakime Use Tepe). Most of the sites settled at the end of the Early

9 This has to remain an assumption, however likely, as long as data from comprehensive archaeobotanical and archaeozoological research are lacking, which makes it difficult to evaluate ancient flora and fauna on a regional scale (Ur in Laneri et al. 2008b, 201 and Laneri et al. 2008a; Ur / Hammer 2009).

Io Rosenberg et al. 1998. Macrofossil analysis has been conducted in the region south of the Tur Abdin; it indicates a reduction of wooded vegetation at the end of the Early Bronze Age (Deckers / Riehl 2007, with additional literature).

II Both in Giricano and Ziyaret Tepe bones and antlers of deer and other wild animals have been excavated (author's observation). A detailed analysis is ongoing and will be published soon within the scope of the final publi- cations. Results from Hirbemerdon Tepe support this idea (Berthon in Laneri et al. 2008b, I96-200). Historic sources from the reign of Aššur-bēl-kalâ (I073-I056 BC) corroborate this by mentioning gazelles, ibex, and deer being bred there (Radner 2006, 284).

I2 Especially in Ziyaret Tepe an unusually large amount of charred grain was excavated (author's observation) and in Giricano the presence of numerous grape seeds is known (Andreas Schachner, pers. comm.). From Hirbemerdon Tepe grape pips and processing installations for wine have been identified (Laneri et al. 2008b, I86-I87).

I3 Due to intensive agricultural activities and irrigation in modern times it is not possible to evaluate this question definitively, as almost no features that could support or refute this hypothesis have been preserved. 
Bronze Age and in the Middle Bronze Age were for this reason located on higher ground, on the second or third river terrace or along and between the tributaries and seasonal streams; they were thus secure from river flooding and at the same time it was possible to cover the area with a dense network of settlements. East of the Batman $\mathrm{Su}$, where the mountain range of the Tur Abdin abuts the Tigris River in the south and the landscape changes to a high-relief terrain, suitable housing space can be found mainly on strategic routes along the watercourses and through the mountains, confining the settlement network to specific areas and transversal routes.

\section{Historical and material evidence}

If we turn our attention to the historical sources and monuments for the upper Tigris region in the late third through mid-second millennium, it becomes evident that the region was always part of the sphere of interest of northern Mesopotamian rulers and polities. ${ }^{\mathrm{I4}}$ It is believed that parts of the region played an integral part in the transport and trade route system in the third and second millennium.I5 Its importance lies in its proximity to the copper source at Ergani Maden and to several inter-regional routes connecting the Mesopotamian plains with the Anatolian highlands, giving access to rich resources. The most important routes, mainly attested in Assyrian sources (Kessler I980; I995; Radner 2006), lead across the Tur Abdin mountains via north-south oriented valleys (Göksu, Savur Çay) connecting the upper Tigris valley with the region south of it.

Natural resources, the intermediary position of the region, and its ideologically charged landscape at the headwaters and sources of the two major rivers, the Euphrates and the Tigris, prompted several attempts to incorporate the upper Tigris region into the northern Mesopotamian entities or at least to utilize it. Evidence for this can be found in the victory stela of the Akkadian king Narām-Sîn (2254-2218 BC) from Pir Hüseyin, ${ }^{16}$ or the Mari archive. After the period covered by the Mari archives and a gap in the historical record that has begun to be bridged, I7 the number of historical sources increases, especially with the Mittanian and Assyrian expansion and the region's incorporation into these empires (Radner $2004,72)$.

\section{A short history of research}

The first significant archaeological survey in the regions between Bismil and Cizre was conducted by Guillermo Algaze between I988 and I99I within the framework of a reconnaissance project along the Tigris and Euphrates Rivers (Algaze 1989; Algaze et al. 199I). The Middle Bronze Age ceramic evidence was difficult to identify at this stage and was interpreted as 'Classical period red/brown washed

I4 posed by the lack of historical sources from the region have been stressed by Norbert Karg (Karg I999, 272-283). Further research on historical sources for this region in different periods has been presented by Kessler I980; Liverani I995; Radner / Schachner 200I; Radner 2004; and Sallaberger 2007 (with further literature).

I5 For a discussion of the different trade routes and especially the upper Tigris region: Larsen 1967; 1976;
Muhly I973, I99-208; Kessler I980; Nashef I987; KellyBuccellati I990; Forlanini 2006.

I6 Börker-Klähn I982, I33, fig. 25. A new survey project is being conducted by Brian Peasnall and Guillermo Algaze (Peasnall / Algaze 2010).

I7 E.g., by cuneiform tablets from an illicit excavation, allegedly found in the upper Tigris region (Karg I999, 274-275, with additional literature). 
ware'(RBWW), and ascribed to the Roman-Byzantine period (Algaze I989, 245, 249; Algaze et al. I991: I82-I83, I98). The assumption of this apparent lack of Middle Bronze Age pottery led to the proposal that either there was a thus far unrecognized ceramic assemblage in use in this period or there was an actual absence of Middle Bronze Age occupation. The first scenario turned out to be correct when excavations under the direction of Veli Sevin commenced at Üçtepe, accompanied by a survey project covering the western part of the region between Diyarbakır and Bismil (Köroğlu I998, I09-IIо; Özfirat 2006, 45). The Üçtepe assemblage was first presented in 1992 (Sevin I992; I993) and was completely published in 2006 by Aynur Özfirat (Özfirat 2006). It shows significant conformity with the material from the recent excavations and can be dated by stratigraphy and two associated Khabur Ware jars (Sevin I993, I77, fig. 7; Özfirat 2006, 26-27, 53, pl. 90.I-2, pl. 9I.I,3).

With the initiation of the rescue projects, a survey at Ziyaret Tepe brought to light more of this mysterious Red Brown Wash Ware, which was now identified by Timothy Matney with the Middle Bronze Age occupation of the site (Matney I998, II-I2; I999a; I999b; McDonald in Matney et al. 2003, I83-I86).

Except for the Üçtepe excavation, which started earlier, all the major excavations in the area were performed as part of the salvage project mentioned already. Among the sites excavated during this project, Middle Bronze Age material was found at Kavuşan Höyük,18 Ziyaret Tepe, ${ }^{19}$ Müslümantepe, ${ }^{20}$ and Hirbemerdon Tepe (Laneri et al. 2006; 2007; 2008a; 2008b) on the southern bank of the Tigris, and at Giricano, ${ }^{21}$ Kenan Tepe (Parker / Dodd 2003; Parker et al. 2004), and Salat Tepe (Ökse / Görmüş 2006; Ökse 2006; 2007) on the northern bank, and at Türbe Tepe, ${ }^{22}$ north of the confluence of the Bohtan Su and the Tigris.

The importance of this period and its material culture's characteristics and peculiarities are now a focus of research for many projects along the upper Tigris River, and the previous perceived gap in the data is steadily being replaced by results obtained from sites in the region.

\section{Ziyaret Tepe - an urban settlement?}

Ziyaret Tepe is a large mounded site located on a river terrace on the southern bank of the Tigris. It consists of a high mound of approximately 5 ha in size surrounded by a lower town of 29 ha in area.

The importance of the site was first recognized by Karlheinz Kessler (Kessler 1980), who argued that it should be identified as the Late Assyrian provincial capital Tušhan (Middle Assyrian Tušhu) on the northern border of the Assyrian empire. ${ }^{23}$

I8 For preliminary information on the Middle Bronze Age levels exposed at Kavuşan Höyük see Kozbe et al. 2004; <http://edebiyat.ege.edu.tr/bolumler/arkeoloji/ Protohistorya/ English/Projeler/kavusan.htm> (accessed 20II-O2-OI); <http://arkeoloji.ege.edu.tr/Protohistorya/Projeler/excavatio ns_at_kavusan_hoyuk.htm> (accessed 20II-O2-OI).

I9 Matney I998; I999a; I999b; Matney et al. 2002a; 2003; Matney / Rainville 2005; Bartl 2005; Roaf / Schachner 2005; Bartl 2012.

20 I am indebted to Eyüp Ay for letting me visit his excavation in the summer of 2009 and giving me the opportunity to examine the results on site.
2I Schachner 2002a; 2002b; 2003a; 2003b; Radner 2004; Roaf / Schachner 2005; Bartl 2005. A detailed analysis of the architecture and some of its material evidence is presented in Bartl 20I2, hence at this point only a short summary will be given in order to avoid repetitions.

22 I am indebted to Haluk Sağlamtemir for allowing me to visit Türbe Tepe in 2005 and giving me the opportunity to study the results on site.

23 This identification is now accepted by most scholars. For a re-evaluation of the proposed identification of Üçtepe with Tušhan (Köroğlu 1998, I03-106), see Radner / Schachner 200I, 754-757; Radner 2004, II5. 
Fig. 3 | Middle Bronze Age architecture from Operation E. The Brightly Burned Building (left) and the White Plaster Building (right).

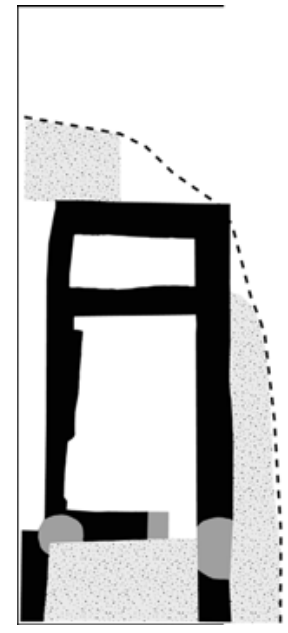

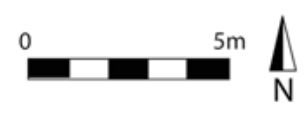

pebble floor

wall - preserved

wall - reconstructed

edge of the site

The first systematic recording was done in 1989 within the scope of the reconnaissance project along the Tigris and Euphrates Rivers (Algaze et al. I99I, I83). Since I997 extensive research has taken place on a regular basis under the direction of Timothy Matney of the University of Akron, Ohio. Between 2000 and 2005 the Institut für Vorderasiatische Archäologie of the Ludwig-Maxilimians-Universität München participated in the investigations at Ziyaret Tepe ${ }^{24}$ with the aim of excavating a $5 \mathrm{~m}$ wide and $45 \mathrm{~m}$ long step trench, called Operation E, running down the eastern side of the high mound. The principal goal was to understand the sequence of occupation at the site and synchronize it with that of other sites such as Giricano on the other side of the Tigris.

\subsection{The Brightly Burned Building}

The occupational sequence observed in step trench E covers the Early Bronze Age through the Medieval Period. The most interesting, and by far most spectacular, discovery is a Middle Bronze Age singleperiod building destroyed by a fire of exceptional violence. The intense heat fired parts of the collapsed ceiling as well as the mud-brick walls and turned them into a kaleidoscope of bright colors ranging from red to orange, yellow, green, gray, and black. The excavated part of the building, which was for obvious reasons called the Brightly Burned Building (henceforth BBB), was exposed over an area of about I2 $\times 6 \mathrm{~m}$, including two extensions to the original step trench (fig. 3 ). The architecture consists of two rooms of unequal size, a paved external surface to the east of it, and part of an enclosed courtyard to the south. Of the two rooms excavated completely, the northern one is quite narrow and shows no sign of an entrance, aside from a small, approximately square, $40 \times 40 \mathrm{~cm}$ opening in the wall between this room and the southern one. The latter is almost four times as big; an entrance can be reconstructed at its southeastern corner, later destroyed by a pit. Both rooms were filled with burnt debris from the first floor and ceiling of the building, covering the original inventory of the rooms. The debris in the northern room consisted of the collapse of the ceiling and several fragments of an unbaked clay container prob-

This project also included the excavation of Giricano, on the opposite side of the Tigris about $5 \mathrm{~km}$ upstream. 
ably intended to store grain. Interestingly, parts of this container were also found in the southern room, indicating that the floor plan of the first floor may have deviated from that of the rooms below.

The debris in the southern room covers a homogeneous, densely packed layer of differently colored ash of up to $50 \mathrm{~cm}$ height, suggesting storage of straw. ${ }^{25}$ The collapsed floor was made out of several layers of straw- and pebble-tempered mud, indicating repeated repairs, and bore the impressions of beams and reeds from the ceiling construction on the lower side.

Numerous vessels were found that originated from the first floor; a bin made out of mud bricks was preserved in the southwestern corner and several other fragments of unfired clay containers, lids, and other storage devices were recovered.

The contemporary open space to the south contained sherds of large storage jars and fragmentary burnt wooden beams; the surface to the north of the BBB, which abuts the northern room at a slightly higher level, was cut away by a later foundation trench and generated almost no finds.

The pottery assemblage from the BBB consists of the typical deep and shallow carinated bowls, cooking ware vessels with or without handles, and storage jars. ${ }^{26}$ However, the intensive burning often makes it impossible to assign them to the group of Middle Bronze Age RBWW, as the original surface treatment cannot be identified in all cases. The forms, however, can be attributed to the spectrum typical of other Middle Bronze Age sites in the region. ${ }^{27}$

${ }^{14} \mathrm{C}$-samples from the debris of the BBB indicate a date in the second quarter of the second millennium (Bartl 2005, I57, fig. 6; Roaf in Mathney / Rainville 2005, 22), between the $1^{\text {th }}$ and $\mathrm{I}^{\text {th }}$ century $\mathrm{BC}$, which may explain the low percentage of sherds with the typical thick RBWW surface treatment.

The building seems to have been used for storage in the basement rooms and for living and domestic activities in the upper story. This is corroborated by objects like calculi (tokens), which may have been used for domestic-administrative purposes, ${ }^{28}$ and several animal figurines and a female baked clay figurine (Roaf in Matney / Rainville 2005, 22, fig. 3c; Bartl 20I2, fig. 5), which were found above the collapsed ceiling of the southern room and may indicate that domestic-ritual tasks were carried out here.

\subsection{The White Plaster Building}

To the north of the BBB a small portion of an earlier building was uncovered. It is best recognized by the multiple white plaster layers on its walls, for which reason it was called the White Plaster Building (henceforth WPB). The main characteristic of this building is the entrance, which is stepped and opens onto a small corridor with another niche in its southern wall leading to two doorways (fig. 3). The purpose of this building is still unclear, as the area exposed is too limited to provide a clear idea of its function.

25 This is supported by numerous burnt bones of mice, which may have been living in the room during that period.

26 For a preliminary assessment of the pottery see McDonald in Matney et al. 2003, I83-186, figs. 6-8; Bartl 2005; Bartl 2012.

27 Bartl 2005, fig. 8; Üçtepe (level ıI): Özfirat 2006; Kenan Tepe: Parker / Dodd 2003; Hirbemerdon Tepe: Laneri et al. 2006, 2008b; Salat Tepe: Ökse 2006, and her article in this volume.

28 Parallels can be found in Tell Munbaqa (Werner in Czichon / Werner 1998, 229-233, pl. 139.2639-2667) or Tell 'Atīğ (Fortin I989, 47-48, figs. I5-I7). Yet the interpretation of calculi as a sign of administrative activities must be considered with caution, as argued in Pfälzner 2008, I76. 


\subsection{The late third millennium levels}

The layers beneath the WPB and BBB are characterized by the presence of hemispherical Dark Rimmed Orange Bowls (DROB), ${ }^{29}$ a type-fossil for the late third and early second millennium in the upper Tigris region that seems to have been produced locally and exported to the Khabur region, where it occurs occasionally in Akkadian and post-Akkadian levels (e.g., Tell Brak: Oates et al. 200I, I62). A comparable dating is suggested at several other sites where an assemblage of DROB types, often mixed with pottery identified as RBWW, $3^{\circ}$ precedes the Middle Bronze Age occupation and has been interpreted as possibly Early Bronze Age-Middle Bronze Age transitional.3 Due to the limited area available for excavation, only several pebble floors associated with a mud-brick wall were uncovered.

\subsection{The Mittani levels}

The levels above the BBB consist of several pits covered by a series of more than 20 external surfaces and associated features. The material evidence is typical for the early Mittanian period and has parallels throughout northern Mesopotamia (McDonald in Oates et al. 1997, 62-77; Pfälzner 1995, pl. I-66). As the two ceramic assemblages show virtually no connection, there must have been a short gap in the history of occupation, as observations from Giricano seem to confirm (Schachner in Radner 2004, 5).

\section{Giricano - a small fortified settlement?}

Giricano, first identified by Algaze (Algaze et al. I99I, I83, fig. 2b), is located east of Bismil on the northern bank of the Tigris, atop an almost completely eroded river-terrace (Doğan 2005, 76-77, fig. 2, fig. 4, river-terrace T2). The site covers an area of approximately 2 ha and is located between two similar-sized settlement sites: Kenan Tepe to the east and the as yet unexplored site of Çayırlık Tepe to the northwest. The floodplain of the river, which here flows southwards, defines the southern limit of the site and the land under direct control of the settlement, and provides a relatively easy river crossing to other sites with Middle Bronze Age levels on the southern bank of the river, such as Kavuşan Höyük and Ziyaret Tepe.

Excavations took place from 2000 through 2003 under the direction of Andreas Schachner of the Institut für Vorderasiatische Archäologie at the Ludwig-Maximilians-Universität. ${ }^{2}$ The chronological sequence of occupation uncovered at Giricano covers the Chalcolithic, the early part of the Early Bronze Age, the Middle Bronze Age, the Mittanian period, the Middle Assyrian period, and the Iron Age. The levels of the second millennium $\mathrm{BC}$, which take centre stage in this paper, are embedded between layers of the Iron Age and those of the early third millennium.

29 For an analysis of the fabric and its provenance, see Kibaroğlu 2008 .

30 However, it has to be noted that no precise definition of RBWW has been agreed (see Bartl 2005, I55, fig. 3, n. I3; Bartl 20I2, n. 27, n. 63) and that the surface treatment of the wares associated with DROB is much more precise, with a very competent control of the firing process, unlike the extensive variations found in the RBWW from the subsequent period.
3I Hirbemerdon Tepe (sub-phase B): Laneri et al. 2008b, I87-I92; Salat Tepe (level 2): Ökse / Görmüş 2006, I88-I89; Üçtepe (level I3-II): Özfirat 2006, 59.

32 This project was funded by the Deutsche Forschungsgemeinschaft as part of the research project The Northern Frontiers of Mesopotamia. It also included the research at the nearby site of Ziyaret Tepe, offering a first possibility of comparing the sites' connection andstratigraphic development and the relation between a small village and a large urban settlement. 


\subsection{Mittani and Middle Assyrian period}

Both Mittanian and Middle Assyrian occupational remains33 were heavily disturbed by erosion, later pits, and medieval graves. Their architecture could be reconstructed, thus far, only in parts; it features structures with small walls, rebuilt several times with slightly differing alignments. In the older levels, a building area and an open space for different activities, such as metalworking, could be distinguished in the more recent levels; the area changed its character gradually to a storage and later a dumping area. Thus several pits were dug, cutting the earlier second millennium buildings beneath, and later filled with waste; they contained sherds of the standard Middle Assyrian pottery assemblage (Schachner $2002 \mathrm{~b}, 26-35)$. Close to one of these pits a small cuneiform archive was found in a jar, which was sealed with the base of a bowl. The date of these tablets between 1068 and 1069 BC gives an approximate terminus post quem for the end of Middle Assyrian control over the area (Radner 2004, II5-II8, I36).

\subsection{Middle Bronze Age}

The Middle Bronze Age occupation can be subdivided into two successive building complexes, represented by buildings A/D and by Building C.34 Each building has several sub-phases, indicating different building stages and reinforcements. A structure that was excavated at the western foot of the mound, Building B, is part of a fortification system and seems to have been in use in both phases.

\section{Building C}

The latest Middle Bronze Age building complex (Building C) seems to have covered the entire central part of the mound and is characterized by a courtyard and several adjacent room units. The northern part of the courtyard was paved with river cobbles and is abutted by a wall with three rooms, which were originally plastered with a layer of lime on the interior, as can be seen in two blocked doorways and several fragmentary floor and wall surfaces. The northern part of this unit of rooms has been subject to considerable erosion, yet the remains show some reinforcements of walls, recognizable in building joins, that suggest several phases of occupation and reinforcement. On the southern side of the mound a second unit of rooms was identified as being part of Building C. At least five rooms with the same alignment (rooms A-6 to A-Io) abut the central courtyard. This architectural unit can be subdivided into at least two different phases of occupation, as can the northern unit. It features a central, probably open area, with remains of ovens, benches, and other installations, and surrounded by rooms, which makes an interpretation as a working area plausible; however, it is not entirely clear whether purely domestic or communal activities took place there. The material evidence from this building complex has to be treated with caution, because the northern room unit is partly disturbed. The inventories discovered in situ can generally be assigned to the end of the Middle Bronze Age (Bartl 20I2) and are characterized by

33 A preliminary publication of the Middle Assyrian levels can be found in: Schachner 2002b, 27-28; Schachner in Radner 2004, 5-9. A more detailed analysis including the Late Bronze Age levels on the southern slope is in progress.
34

The letters were assigned to the building complexes according to their date of excavation and not their stratigraphic sequence. 


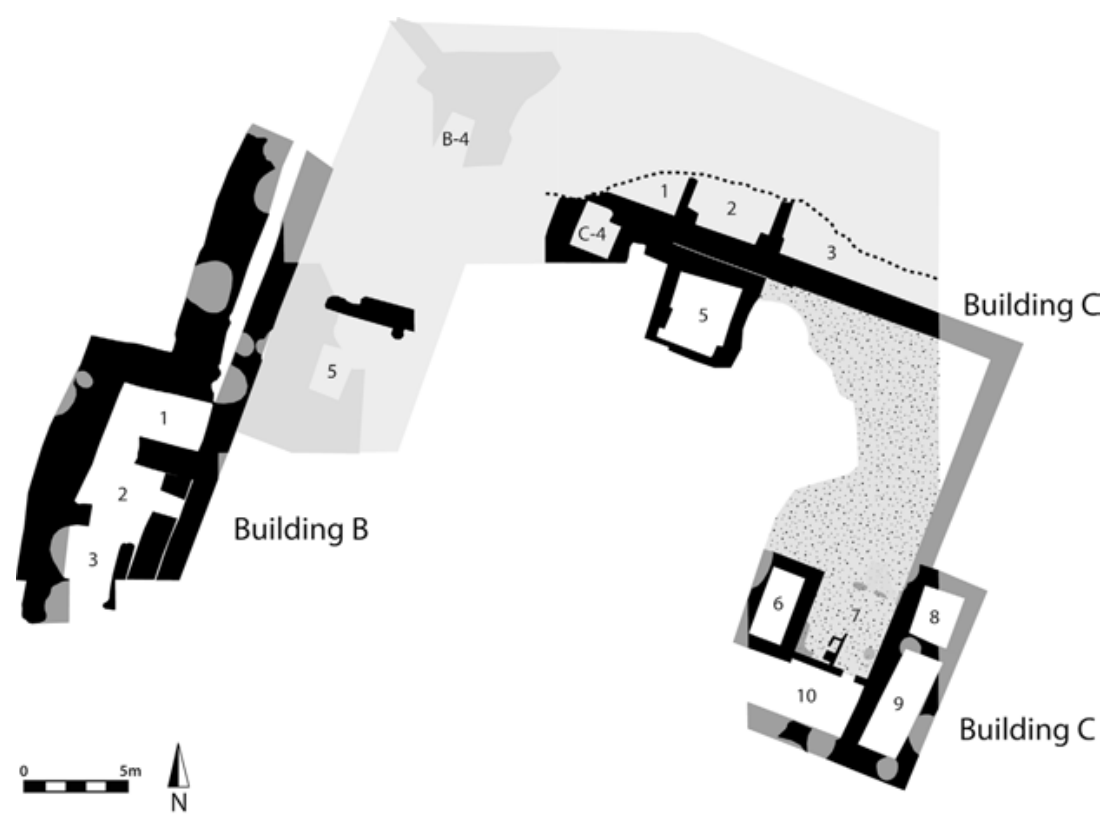

Fig. 4 | Architectural plan of the later Middle Bronze Age occupation - Buildings B and C.

sherds of large storage jars of RBWW types, of band-painted pottery that may be related to Khabur ware, and of unpainted vessels and bowls. Objects such as grinders, pestles, mortars, clay stamps with concentric circles, and footed terracotta plates can be connected to domestic activities such as processing foodstuffs and the production of equipment.

\section{Building A/D}

The architecture of Building $\mathrm{C}$ is separated from its predecessor, the building complex Building A/D, by a thin layer of ashy debris covering almost half the mound. The northern part (Building A) is quite well preserved and consists of two rows of small rooms which were partly cut into the northern side of the Chalcolithic and Early Bronze Age mound and partly erected on a mud-brick platform. The floors of the rooms were covered with lime plaster and, as no doorways have been identified, it is likely that these were basement rooms accessed from above.

On the western slope of the mound, erosion has affected preservation even more seriously. Only a few remains of stone foundations resting on the mud-brick platform have survived. On the southern side of the mound, however, parts of another structural unit (Building D) have been exposed: at least four rooms with several building phases can be distinguished. On one of the walls an unusual building technique was observed, which involved a layer of reed and thin wood covering the stone foundation. A similar building technique has also been observed at Salat Tepe (Ökse / Görmüş 2006, I87). The contemporaneity of Building D with Building A can be established from the stratigraphic sequence, level of foundation, and alignment. 

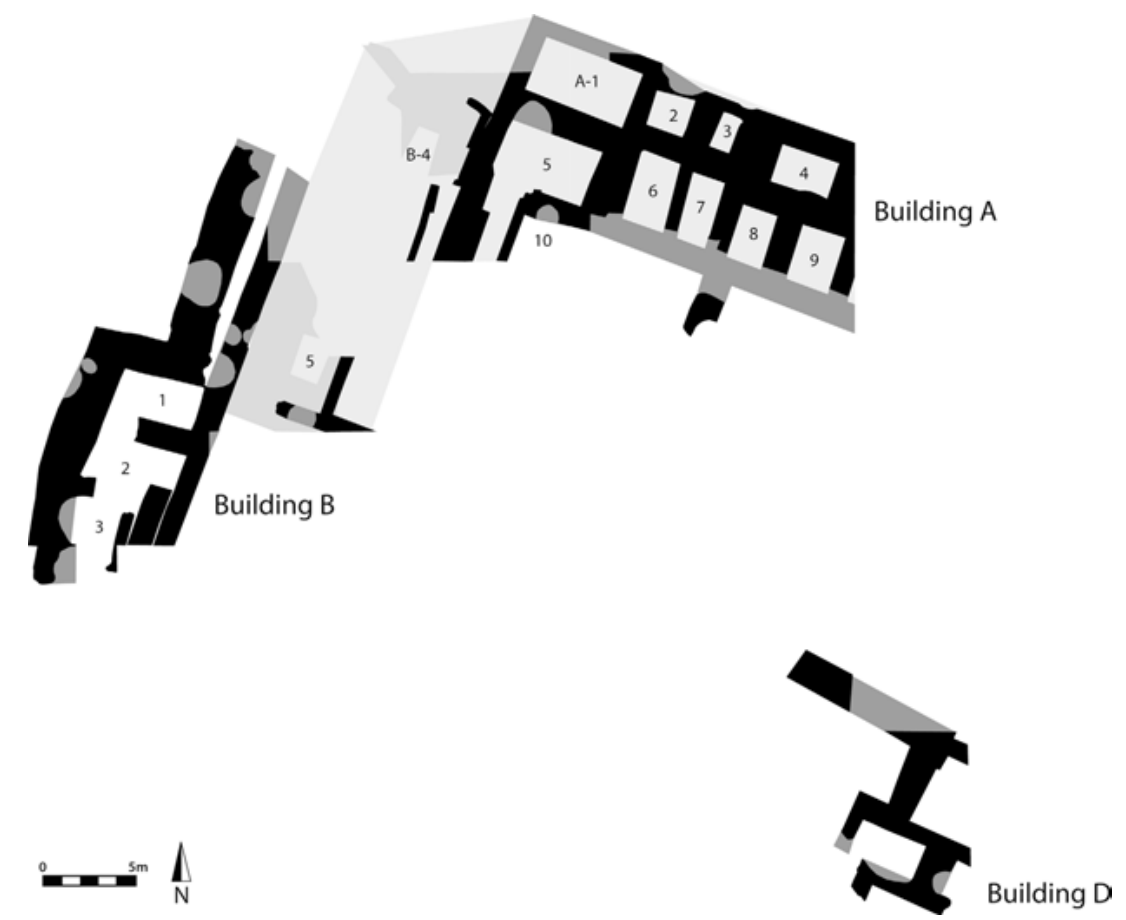

Fig. 5 | Architectural plan of the earlier Middle Bronze Age occupation Buildings $\mathrm{A} / \mathrm{D}$ and $\mathrm{B}$.

\section{Building B}

It is not entirely clear whether the structures at the western foot of the mound were in use at the same time as both Building C and Building A/D, because the steep slope has caused most of the features to erode. Yet the main characteristics of the architecture - a monumental fortification and a pisé structure that supports a mud-brick platform - would have been useful in both phases and Building A, at least, was directly linked to the construction of the fortification and platform that covers parts of the northern and western slope of the mound. This construction made it possible for the abandoned and probably partly eroded site on the river terrace to be prepared for Building A. This can also be observed on the southern slope northwest of Building D, where a monumental wall appears to retain parts of the central mound. The mud-brick architecture of the fortification itself has not survived, yet the broad foundations indicate a massive fortification. Several rooms arranged between the fortification and the pisé wall (Rooms B-I to B-3) contained large storage jars of RBWW type, as did two small rooms embedded into the mud-brick platform (Rooms B-4 and B-5). Further finds include clay stamps like those found in Building C,35 fragments of portable andirons, $3^{6}$ and a perforated bronze tube used as a tip for a drinking straw; 37 most of these finds seem to have come from the upper story, as indicated by their findspot in the fill of the rooms or in debris accumulated after the abandonment of the building. Only in one room were

35 Bartl 20I2, figs. 2-3. Similar clay stamps were found in Salat Tepe (Ökse / Görmüş 2006, I82, fig. 38), Nuzi (Starr I937-I939, 59, pl. 97), Tell Brak (Oates et al. I997, 47; fig. I80.23), and Üçtepe (Özfirat 2006, pl. 94.5-6, 95.9-II). For a more general discussion of terracotta stamp seals of this kind see von Wickede I990, 52-6I.

36 Bartl 20I2, fig. 3. The portable andirons have parallels in Salat Tepe (Ökse / Görmüş 2006, I85, fig. 46), Hirbe- merdon Tepe (Laneri et al. 2006, I66-167, figs. 9.2-3; I6), Kenan Tepe (Parker / Dodd 2003, 36), Üçtepe (Özf1rat 2006, 53-54, fig. 95.13), and Ziyaret Tepe.

37 Similar perforated tubes as tips for beer-straws were mostly found in Middle Bronze Age and Late Bronze Age layers in numerous sites in the ancient Near East, e.g., Tell Munbaqa (Czichon / Werner I998, 92-94, pl. 89-90) and the lower town of Tell Bazi (Otto 2006, II6, fig. 57.5). 
finds preserved in situ: a pottery assemblage and an oven-installation consisting of a horseshoe-shaped hearth incised with a line-and-dot pattern. $3^{8}$

Building B is thus an integral part of the foundation platform for Building A and it is likely that during the Middle Bronze Age the whole mound was encircled by the fortification wall.

\section{Conclusion}

In conclusion, Giricano and Ziyaret Tepe have to be understood as part of a local, self-contained culture which prospered in the upper Tigris region during the late third and the first half of the second millennium. This cultural complex is situated between the East Anatolian highlands, featuring Transcaucasian elements, to the north and east, the valleys of the upper Euphrates to the west, and the north Mesopotamian plains south of the Tur Abdin (Mardin Dağları), featuring Khabur Ware and second millennium horizons.

This culture seems to have had its first florescence during the period at the end of the third millennium when DROB were in use. Not only in the excavations, but also on survey projects (Özfirat 2006; Peasnall / Algaze 20I0) they have been identified at numerous sites as preceding the bulk of the RBWW. The hiatus at Giricano and Ziyaret Tepe prior to the appearance of this pottery assemblage may imply the change to or advent of a new settlement pattern and sociopolitical order. Yet, as mentioned above, pottery found with the DROB has certain similarities with the surface treatment of the RBWW and the quantity of DROB declines with the beginning of the Middle Bronze Age. Whether this should be seen as part of a change in pottery style or as the result of a broader impact is not entirely clear. The most characteristic feature of the Middle Bronze Age pottery tradition (RBWW), however, remains ubiquitous until the end of the period.

This observation can be corroborated by the evidence from Ziyaret Tepe and Giricano. After the latter was resettled in the late third millennium (Schachner 2002b, 48-49), the ancient mound was leveled in parts and a mud-brick and pisé platform was erected that included a fortification surrounding the site (Building B). Resting upon this was a two-storied monumental building (Building A/D), which was partly cut into the pre-existing slope of the ancient mound. After a short phase of decay (Bartl 20I2, n. 68), the structures were leveled and the subterranean rooms filled with debris to prepare the surface for a later building (Building C). Building $\mathrm{C}$ followed approximately the same orientation as its predecessor building, despite its different architectural layout. However, both Middle Bronze Age building complexes seem to be the results of a central organization involved in the planning and construction of the settlement, as can be concluded from the standardized building techniques.

A similar building technique and character can be observed at Salat Tepe, level II. Here five room units were constructed around a central courtyard on a mud-brick platform.39 Similarities in the architecture are matched by the objects found within the settlements: a homogeneous assemblage of large storage jars of RBWW,40 smaller quantities of small vessels such as carinated bowls and cooking ware

38 Schachner 2002a, 594, fig. II.I-2. Parallels dated between 1900 and $\mathrm{I} 600 \mathrm{BC}$ have been found in Tell Mozan (Kelly-Buccellati 2004, 74). For general discussion of such hearths see: Smogorzewska 2004.

39 The complex has been interpreted by the excavators as a facility for the storage and administration of agricultural products (Ökse / Görmüş 2006, I87).

40 The pottery assemblage from Building A/D covers the first half of the Middle Bronze Age. Whether residual sherds of DROB can be interpreted as evidence for a late third millennium occupation is not entirely clear. A similar situation can be observed at Hirbemerdon Tepe (sub-phase B) and Kavuşan Höyük. The pottery from Building $\mathrm{C}$ can preliminarily be dated to the second half of the Middle Bronze Age - at least according to some in situ inventories from the southern slope (Bartl 20I2). 
vessels, clay stamps, andirons, grinding stones, mortars, and terracotta work platforms. This supports an interpretation of the site as a storage and processing facility for agricultural products.

After several occupational phases characterized by different rebuilding activities, the architectural complex was abandoned before the site was reoccupied in the Mittani and Middle Assyrian period.4I Now the settlement is of a different type, showing characteristics of a village-like structure consisting of a series of individual houses built in an agglutinating manner. Despite the fact that political governance changed dramatically between these periods, the purpose of the site seems to have stayed the same. $4^{2}$

Regarding continuity and chronological development at Giricano and Ziyaret Tepe, it has to be noted that the two sites had a different character and thus a different function. Even though the BBB in Ziyaret Tepe is hard to interpret due to the small area uncovered so far, the objects contained within it indicate a use of the rooms that is partly domestic (first story) and partly economic (subterranean rooms). Leaving aside the obvious problems with the pottery assemblage arising from the badly preserved surface, the ceramics comprise storage vessels, carinated bowls and vessels, beakers, a lid, and clay containers. Parallels with the pottery from Üçtepe (levels II-IO) (Özfirat 2006, I9-38), Salat Tepe (level II) (Ökse / Görmüş 2006, I90), and Hirbemerdon Tepe (sub-phase A) (Laneri et al. 2007, 8I; 2008b, I79) suggest the approximate contemporaneity of these levels in the later part of the Middle Bronze Age.43

The WPB and older levels yielded only a limited amount of pottery, making an accurate assessment of their date difficult. It has to be noted, however, that both DROB and pottery that has been identified as a type of RBWW occur in levels earlier than the WPB, indicating a date for these levels before the turn of the third millennium, contemporaneous with Hirbemerdon Tepe (sub-phase B) (Laneri et al. 2007, 8I; 2008b, I79), Kenan Tepe (Parker / Dodd 2003), Üçtepe (level I3-I2) (Özfirat 2006, I5-I6, 26), and Kavuşan Höyük (Kozbe 2009).

At present, it can be concluded that the upper Tigris region did not suffer from the collapse or decline of urban institutions that affected some parts of northern Mesopotamia at the end of the third millennium. It appears instead that in this region there was increased precipitation at the end of the Early Bronze Age (see above) and it was therefore able to develop independently into a self-contained culture, with an independent pottery tradition characterized by DROB and RBWW. Moreover, the diversity of landscapes and agricultural products, noted above, allowed for the formation of an urban-style society, as is suggested on the basis of large Middle Bronze Age centers such as Pir Hüseyin (23 ha?), 44 Ziyaret Tepe (minimum of 6 ha), 45 Üçtepe (minimum of 8 ha),,$^{6}$ and Hirbemerdon Tepe (about Io ha) (Laneri et al. 2008b).

4I Schachner in Radner 2004, 9. A short hiatus is indicated by a layer of debris. However a certain amount of continuity and even reuse of the pre-existing platform can be postulated by the alignment of the architecture and by stratigraphic observations.

The character of the finds, including cylinder seals of Mittani Common Style (Schachner 2002b, 35-37, fig. 27) and the Middle Assyrian archive (Radner 2004), indicate a similar function. It has to be noted, however, that the purpose of the Middle Bronze Age occupation is thus far based solely on the architectural and archaeological evidence. To follow this up, the character of the architecture of subsequent periods still has to be studied in that respect, in order to better understand why it changed and how this change affected the function of the settlement.
43 This correlation is supported by radiocarbon dates (Bartl $2012, n .79^{-80}$ ) which place the BBB in the $\mathrm{I}^{\text {th }}$ and $\mathrm{I}^{\mathrm{th}}$ century.

44 According to Peasnall / Algaze 2010 the whole mound and lower town were settled during the late Early Bronze Age and subsequent Middle Bronze Age.

45 It is not clear whether and, if so, which parts of the lower town were settled during the Middle Bronze Age. Some late third millennium and Middle Bronze Age-Late Bronze Age transitional material evidence from Operation D (MacGinnis in Matney et al. 2002b, 60-62; figs. I4-I9) suggests such settlement, but this could have come in as intrusive material.

46 The high mound, at least, was settled during the Middle Bronze Age (Özfirat 2006). It is, however, likely that a lower town existed as well. 


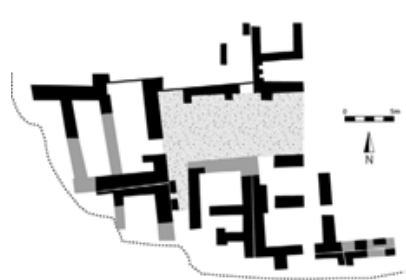

Salat Tepe
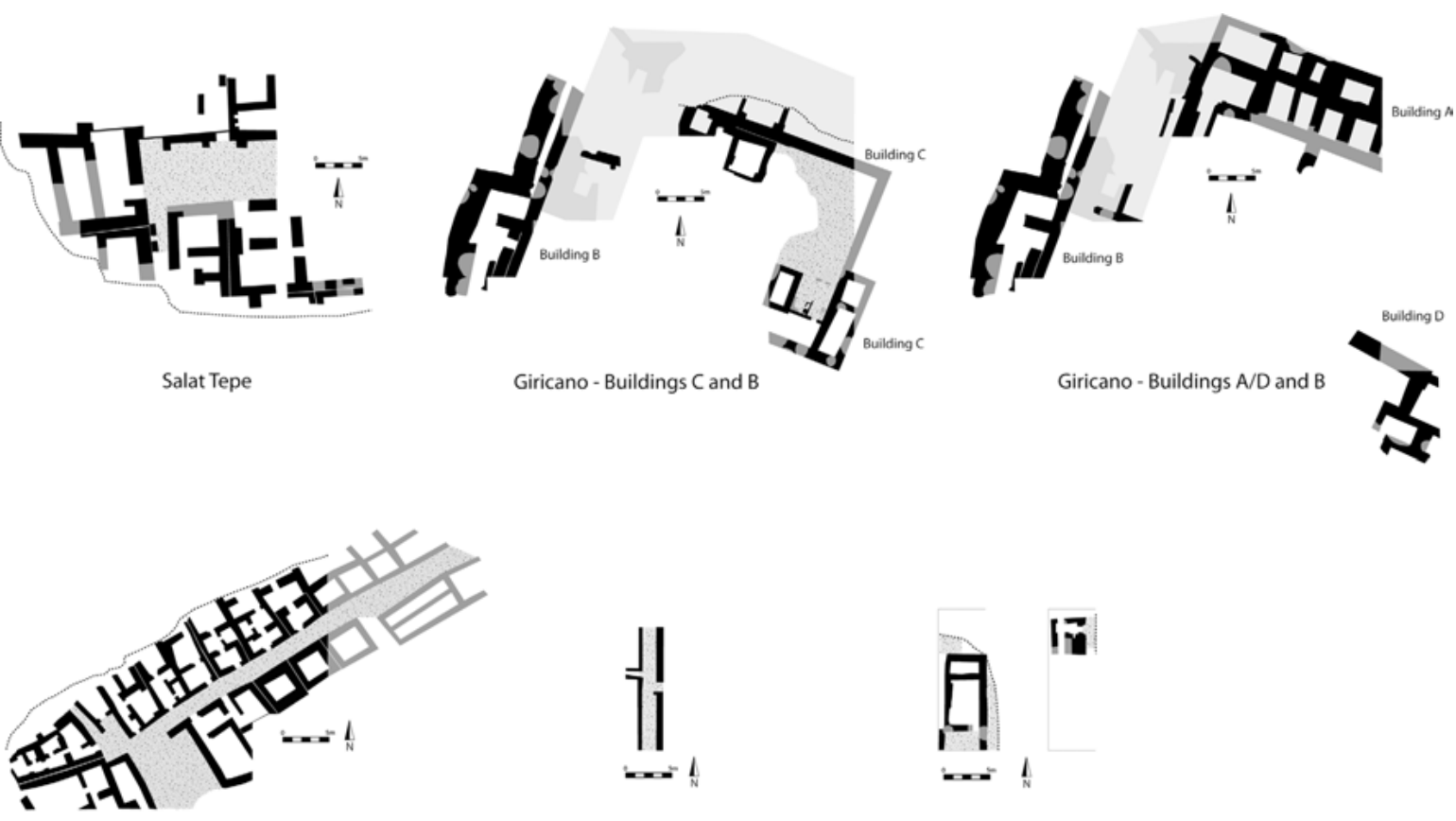

Hirbemerdon Tepe

Giricano - Buildings C and B

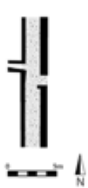

Üçtepe

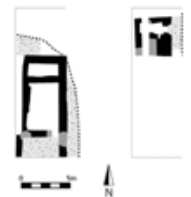

Ziyaret Tepe - BBB (left) and WPB (right)

Fig. 6 | Comparison of building complexes and excavation areas at different sites.

With an evolving complex society, there developed a need to facilitate agricultural activities and production. Diversity of settlements was a response. As well as large urban centers and small village-like settlements, there was a further kind of settlement, consisting of planned single building-complexes to process and store the agricultural products of the surrounding region. Different products would have been processed, depending on the surroundings and the interaction between the sedentary population and pastoralists. This is affirmed by the specialization in products that can be seen in Hirbemerdon Tepe (Hald in Laneri et al. 2008b, I94-I95). Interaction with pastoralists is affirmed by objects known from third millennium highland sites, such as portable andirons or ritual objects that show significant similarities to the repertoire of styles known from eastern Anatolia.

Thus the upper Tigris region presents a unique environment, which provided the population with an abundance of products at a time when decreasing precipitation impacted other areas, such as the plains south of the Tur Abdin, which were more densely populated and agriculturally more dependent on periodic rainfall. This geographically, environmentally, and culturally self-contained area, however, was exposed to different influences due to its position at the gateways to important resources, such as copper and timber, which were in demand in numerous neighboring polities. In this way an urban society with a strong rural element and a dense settlement pattern seems to have evolved in the late third millennium BC and to have flourished until the end of the Middle Bronze Age. With the assimilation of the region into the Mittanian and Middle Assyrian empires, its cultural autonomy disappeared, yet the structures created in the preceding period were adopted and incorporated into the networks of the later empires. 


\section{Bibliography}

Algaze, Guillermo (1989)

"A New Frontier: First results of the Tigris-Euphrates Archaeological Reconnaissance Project, I988”, in: Journal of Near Eastern Studies 48/4, 24I-269.

Algaze, Guillermo / Breuninger, Ray / Lightfoot, Chris / Rosenberg, Michael (I99I)

"The Tigris-Euphrates Archaeological Reconnaissance Project: A preliminary report of the I989-1990 season", in: Anatolica I7, I75-229.

\section{Bartl, Peter V. (2005)}

"The Middle Bronze Age on the Upper Tigris. New evidence from the excavations at Giricano and Ziyaret Tepe", in: Archäologische Mitteilungen aus Iran und Turan 37, I53-162.

Bartl, Peter V. (2012)

"Giricano and Ziyaret Tepe: Two Middle Bronze Age Sites in the Upper Tigris Region", in: Nicola Laneri / Peter Pfälzner / StefanoValentini (eds.), Looking North. The socio-economic dynamics of the northern Mesopotamian and Anatolian regions during the late third and early second millennium B.C., (Studien zur Urbanisierung Nordmesopotamiens, Serie D, vol. I), Wiesbaden, I75-I9I.

\section{Börker-Klähn, Jutta (1982)}

Altvorderasiatische Bildstelen und vergleichbare Felsreliefs, (Baghdader Forschungen 4), Mainz.

\section{Czichon, Rainer M. / Werner, Peter (1998)}

Tall Munbaqa - Ekalte - I, Die bronzezeitlichen Kleinfunde, (Wissenschaftliche Veröffentlichungen der Deutschen Orient-Gesellschaft 97), Saarbrücken.

Deckers, Kathleen / Riehl, Simone (2007)

"An Evaluation of Botanical Assemblages from the Third to Second Millennium B.C. in Northern Syria", in: Catherine Kuzucuoğlu / Catherine Marro (eds.), Sociétés humaines et changement climatique à la fin du troisième millénaire: une crise a-t-elle eu lieu en haute Mésopotamie? Actes du Colloque de Lyon, (Varia Anatolica I9), Paris, 48I-502.

Doğan, Uğur (2005)

"Holocene Fluvial Development of the Upper Tigris Valley (Southeastern Turkey) as Documented by Archaeological Data", in: Quaternary International I29, 75-86.

Forlanini, Massimo (2006)

"Étapes et itinéraires entre Aššur et l'Anatolie des marchands paléo-assyriens: Nouveaux documents et nouveaux problèmes", in: Kaskal 3, I47-I75.
Fortin, Michel (1989)

"Trois campagnes de fouilles à Tell Atij: un comptoir commercial du IIIème millénaire en Syrie du Nord", in: The Canadian Society for Mesopotamian Studies Bulletin $\mathrm{I} 8,35-55$.

Hütteroth, Wolf. D. (1982)

Türkei, (Wissenschaftliche Länderkunde 2I), Darmstadt.

\section{Karg, Norbert (1999)}

"Gre Dimse I998: Preliminary Report", in: Numan Tuna / Jean Öztürk (eds.), Salvage Project of the Archaeological Heritage of the Ilisu and Carchemish Dam Reservoirs. Activities in 1998, Ankara, 237-296.

Kelly-Buccellati, Marilyn (1990)

"Trade in Metals in the third Millennium: Northeastern Syria and eastern Anatolia”, in: Paolo Matthiae / Maurits van Loon / Harvey Weiss (eds.): Resurrecting the Past. A joint Tribute to Adnan Bounni, Leiden, II7-I3O.

Kelly-Buccellati, Marilyn (2004)

"Andirons at Urkesh: New Evidence for the Hurrian Identity of Early Trans-Caucasian Culture”, in: Antonio Sagona (ed.), A View from the Highlands: Archaeological Studies in Honour of Charles Burney, (Ancient Near Eastern Studies, Supplement I2), Herent, 67-89.

\section{Kessler, Karlheinz (1980)}

Untersuchungen zur historischen Topographie Nordmesopotamiens nach keilschriftlichen Quellen des 1. Jahrtausends v. Chr., (Beiheft zum Tübinger Atlas des Vorderen Orients B/26), Wiesbaden.

Kessler, Karlheinz (1995)

"Šubria, Urartu and Aššur. Topographical Questions around the Tigris Sources", in: Mario Liverani (ed.), Neo-Assyrian Geography, (Quaderni di Geografia Storica 5), Rome, 55-67.

Kibaroğlu, Mustafa (2008)

Petrographische und geochemische Untersuchungen an archäologischer Keramik aus Nordost-Syrien, Südost-Anatolien, Ost-Anatolien und Ost-Georgien, Unpublished Ph.D. thesis, Eberhard Karls Universität Tübingen, <http://nbn-resolving.de/urn:nbn:de:bsz:2I-opus-

33I47> (accessed 2008-07-OI).

Koliński, Rafał (200I)

Mesopotamian dimātu of the Second Millennium $B C$, (BAR International Series Ioo4), Oxford.

\section{Köroğlu, Kemalettin (1998)}

Üçtepe I: Yeni Kazı ve Yüzey Bulguları Işı̆̆ında Diyarbakır/Üçtepe ve Çevresinin Yeni Assur Dönemi Tarihi Coğrafyası, Türk Tarih Kurumu Yayınları, Ankara. 
Kozbe, Gülriz (2009)

"Excavations at Kavuşan Höyük", <http://arkeoloji. ege.edu.tr/Protohistorya/Projeler/excavations_at_ kavusan_hoyuk. htm> (accessed 20II-O2-OI).

Kozbe, Gülriz / Köroğlu, Kemalettin /

Sağlamtemir, Haluk (2004)

“200I Excavation at Kavuşan Höyük”, in: Tuna, Numan/ Greenhalgh, Jean / Velibeyoğlu, Jâle (eds.), Salvage Project of the Archaeological Heritage of the Ilisu and Carchemish Dam Reservoirs. Activities in 2001, Ankara, 463-503.

Kuzucuoğlu, Catherine (2002)

"Preliminary Observation on the Tigris Valley Terraces between Bismil and Batman”, in: Numan Tuna / Jale Velibeyoğlu (eds.), Salvage Project of the Archaeological Heritage of the Ilisu and Carchemish Dam Reservoirs Activities in 2000, Ankara, 759-77I.

Laneri, Nicola / D'Agostino, Anacleto / Schwartz, Mark / Valentini, Stefano / Pappalardo, Guiseppe (2006)

"A Preliminary Report of the Archaeological Excavations at Hirbemerdon Tepe, Southeastern Turkey, 2005", in: Anatolica 32, I53-188.

Laneri, Nicola / Valentini, Stefano / D’Agostino, Anacleto (2007)

"Hirbemerdon Tepe: A late third to mid second millennium BC settlement of the upper Tigris valley", in: Anatolian Studies 57, 77-86.

Laneri, Nicola / Schwartz, Mark / Ur, Jason A. (2008a) "The Hirbemerdon Tepe Archaeological Project", in: Antiquity 82/3I5 March, <http://antiquity.ac.uk/ projgall/laneri/index.html> (accessed 2008-II-OI).

Laneri, Nicola / Schwartz, Mark / Ur, Jason A. /

Valentini, Stefano / D'Agostino, Anacleto /

Berthon, Remy / Halde, Marie (2008b)

“The Hirbemerdon Tepe Archaeological Project 20062007. A preliminary report on the Middle Bronze Age 'architectural complex' and the survey of the site catchment area”, in: Anatolica 34, I77-240.

Larsen, Mogens Trolle (1967)

Old Assyrian Caravan Procedures, Istanbul.

Larsen, Mogens Trolle (1976)

The Old Assyrian City-State and Its Colonies, Copenhagen.

Liverani, Mario (1995) (ed.)

Neo-Assyrian Geography, (Quaderni di Geografia Storica 5), Rome.

Matney, Timothy (1998)

"The first Season of Work at Ziyaret Tepe in the Diyarbakır Province: Preliminary Report”, in: Anatolica 24, 7-30.
Matney, Timothy (1999a)

"Preliminary Report on Survey at Ziyaret Tepe (Diyarbakır Province), I997”, in: Araştırma Sonuçları Toplantısi I6/2, 255-266.

Matney, Timothy (1999b)

"Surface and Subsurface Survey at Ziyaret Tepe, Diyarbakır Province, I997-I998”, in: Numan Tuna / Jean Öztürk (eds.), Salvage Project of the Archaeological Heritage of the Ilisu and Carchemish Dam Reservoirs Activities in 1998, Ankara, 319-331.

Matney, Timothy / Roaf, Michael / McGinnis, John (2002a)

"Archaeological Excavation at Ziyaret Tepe, Diyarbakır Province, 2000”, in: Numan Tuna / Jale Velibeyoğlu (eds.), Salvage Project of the Archaeological Heritage of the Ilisu and Carchemish Dam Reservoirs Activities in 2000, Ankara, 535-547.

Matney, Timothy / Roaf, Michael / McGinnis, John / McDonald, Helen (2002b)

"Archaeological Excavation at Ziyaret Tepe, 2000 and 200I", in: Anatolica 28, 47-89.

Matney, Timothy / McGinnis, John / McDonald, Helen/ Nicoll, Kathleen / Rainville, Lynn / Roaf Michael / Smith, Monica L. / Stein, Diana (2003)

“Archaeological Investigations at Ziyaret Tepe, 2002", in: Anatolica 29, I75-22I.

Matney, Timothy / Rainville, Lynn (eds.) (2005)

"Archaeological Investigations at Ziyaret Tepe, 2003 and 2004", in: Anatolica 3I, I9-68.

Muhly, James David (1973)

Copper and Tin: The distribution of mineral resources and the nature of the metals trade in the Bronze Age, New Haven.

\section{Nashef, Khaled (1987)}

Rekonstruktion der Reiserouten zur Zeit der altassyrischen Handelsniederlassungen, (Beihefte zum Tübinger Atlas des Vorderen Orients B/83), Wiesbaden.

Nicoll, Kathleen (20I0a)

"Landscape Development within a Young Collision Zone: Implications for the post-Tethyan evolution of the Upper Tigris River System in southeastern Turkey", in: International Geology Review 52/4, 404-422.

\section{Nicoll, Kathleen (2010b)}

"Geomorphic Evolution of the Tigris River, Turkey" $<$ http://serc.carleton.edu/47064>

(accessed 2OII-O2-OI).

Oates, David / Oates, Joan / McDonald, Helen (1997) Excavations at Tell Brak, Vol. 1: The Mitanni and Old Babylonian periods, Cambridge-London. 
Oates, David / Oates, Joan / McDonald, Helen (200I) Excavations at Tell Brak, Vol. 2: Nagar in the Third Millennium $B C$, Cambridge-London.

\section{Ökse, Tuba (2006)}

"A Monumental Middle Bronze Age Building at Salat Tepe on the Upper Tigris (Turkey)", in: Antiquity 80/309 September, <http://antiquity.ac.uk/projgall/ okser/index.html> (accessed 2OII-O2-OI).

Ökse, Tuba (2007)

"Archaeological Evidence for a sixteenth-century BC Earthquake on the Southeastern Anatolian Faultline", in: Antiquity 8I/3I2 June, <http://antiquity.ac.uk/ projgall/okse2/index.html> (accessed 2OII-O2-OI).

Ökse, Tuba / Görmüss, Ahmet (2006)

"Excavations at Salat Tepe in the Upper Tigris Region: Stratigraphic Sequence and Preliminary Results of the 2005-2006 Seasons", in: Akkadica I27/2, I67-197.

Özfirat, Aynur (200I)

Yayla Kültürleri, Istanbul.

Özfirat, Aynur (2006)

Üçtepe II: Tunç Çăgları, Istanbul.

Otto, Adelheid (2006)

Alltag und Gesellschaft zur Spätbronzezeit: Eine Fallstudie aus Tall Bazi (Syrien), (Subartu I9), Turnhout.

\section{Palmer, Andrew (1990)}

Monk and Mason on the Tigris Frontier. The Early History of Tur 'Abdin, (University of Cambridge Oriental Publications 39), Cambridge.

Parker, Bradley / Dodd, Lynn Swartz (2003)

"The Early Second Millennium Ceramic Assemblage from Kenan Tepe, South-Eastern Turkey. A preliminary assessment", in: Anatolian Studies 53, 33-69.

Parker, Bradley / Creekmore, Andrew / Dodd, Lynn Swartz (2004)

"A Preliminary Synthesis of the Cultural History of Kenan Tepe”, in: Numan Tuna / Jean Greenhalgh / Jale Velibeyoğlu (eds.), Salvage Project of the Archaeological Heritage of the Ilisu and Carchemish Dam Reservoirs Activities in 2001, Ankara, 534-602.

Peasnall, Brian / Algaze, Guillermo (2010)

"The Survey of Pir Hüseyin, 2004", in: Anatolica 36, I65-I95.

\section{Pfälzner, Peter (1995)}

Mittanische und Mittelassyrische Keramik. Eine chronologische, funktionale und produktionsökonomische Analyse, (Berichte der Ausgrabung Tall Šēh Hamad/Dūr-Katlimmu 3), Berlin.

\section{Pfälzner, Peter (2008)}

"Redistributive, kommunale und häusliche Vorratshaltung am Unteren Hābūr im 3. Jtsd. v. Chr.”, in: Hartmut Kühne (ed.), Umwelt und Subsistenz der assyrischen Stadt Dūr-Katlimmu am Unteren Hā̄būr, Wiesbaden, I63-I79.

\section{Radner, Karen (2004)}

Das mittelassyrische Tontafelarchiv von Giricano/Dunnuša-Uzibi, Ausgrabungen in Giricano I/Excavations at Giricanno I/Giricano Kazıları I, (Subartu I4), Turnhout.

\section{Radner, Karen (2006)}

"How to Reach the Upper Tigris: The route through the Tūr Ābdīn", in: State Archives of Assyria Bulletin I5, 273-305.

Radner, Karen / Schachner, Andreas (200I)

"From Tušhan to Amēdi: Topographical Questions concerning the Upper Tigris Region in the Assyrian Period", in: Numan Tuna / Jean Öztürk / Jâle Velibeyoğlu (eds.), Salvage Project of the Archaeological Heritage of the Ilisu and Carchemish Dam Reservoirs Activities in 1999, Ankara, 753-776.

Roaf, Michael / Schachner, Andreas (2005)

"The Bronze Age to Iron Age Transition in the Upper Tigris Region: new information from Ziyaret Tepe and Giricano”, in: Altan Çilingiroğlu / Gareth Darbyshire (eds.), Anatolian Iron Ages 5. Proceedings of the Fifth Anatolian Iron Ages Colloquium held at Van, 6-Io August 200I, London, II5-I23.

Rosenberg, Michael / Redding, Richard / Nesbit, R. Mark / Peasnall, Brian (I998)

"Hallan Çemi Tepesi and Post-Pleistocene Adaptions along the Taurus-Zagros Arc", in: Paléorient 24/I, 25-4I.

\section{Sallaberger, Walter (2007)}

"From Urban Culture to Nomadism: A history of Upper Mesopotamia in the late third millennium”, in: Catherine Kuzucuoğlu / Catherine Marro (eds.), Sociétés humaines et changement climatique à la fin du troisième millénaire: une crise a-t-elle eu lieu en haute Mésopotamie? Actes du Colloque de Lyon, (Varia Anatolica I9), Paris, $4 \mathrm{I} 7-456$.

Schachner, Andreas (2002a)

"Vorläufiger Bericht über die Ausgrabungen in Giricano (Diyarbakır/Türkei) 2000”, in: Numan Tuna / Jale Velibeyoğlu (eds.), Salvage Project of the Archaeological Heritage of the Ilisu and Carchemish Dam Reservoirs Activities in 2000, Ankara, 587-6II.

\section{Schachner, Andreas (2002b)}

"Ausgrabungen in Giricano (2000-200I). Neue Forschungen an der Nordgrenze des Mesopotamischen Kulturraums", in: Istanbuler Mitteilungen 52, 9-57. 
Schachner, Andreas (2003a)

"From the Bronze to the Iron Age: Identifying Changes in the Upper Tigris Region. The Case of Giricano", in: Bettina Fischer / Hermann Genz / Éric Jean / Kemalettin Köroğlu (eds.), Identifying Changes: The Transition from Bronze to Iron Ages in Anatolia and its Neighbouring Regions, Istanbul, I5I-I63.

\section{Schachner, Andreas (2003b)}

"Ein Dorf in 'Schubria' - Giricano am Oberen Tigris", in: Alter Orient aktuell 4, 27-3I.

\section{Sevin, Veli (1992)}

"Diyarbakır/Üçtepe höyüğü orta tunç çaği seramiği”, in: Orient-Express 2, I2-I4.

\section{Sevin, Veli (1993)}

“I99I yılı Diyarbakır Üçtepe höyüğü kazıları”, in: Kazı Sonuçları Toplantıs1 I4/I, I75-I9I.

\section{Smogorzewska, Anna (2004)}

"Andirons and their Role in Early Transcaucasian Culture", in: Anatolica 30, I5I-I77.

\section{Starr, Richard F.S. (1937-1939)}

Nuzi: Report on the Excavation at Yorgan Tepa near Kirkuk, Iraq, Conducted by Harvard University in Conjunction with the American Schools of Oriental Research and the University Museum of Philadelphia, 1927-1931, 2 vols., Cambridge.

\section{Tuna, Numan / Öztürk, Jean (eds.) (I999)}

Salvage Project of the Archaeological Heritage of the Ilisu and Carchemish Dam Reservoirs. Activities in 1998, Ankara.

Tuna, Numan / Öztürk, Jean / Velibeyoğlu, Jale (eds.) (200I)

Salvage Project of the Archaeological Heritage of the Ilisu and Carchemish Dam Reservoirs Activities in 1999, Ankara.
Tuna, Numan / Velibeyoğlu, Jale (eds.) (2002)

Salvage Project of the Archaeological Heritage of the Ilisu and Carchemish Dam Reservoirs Activities in 2000, Ankara.

Tuna, Numan / Greenhalgh, Jean / Velibeyoğlu, Jale (eds.) (2004)

Salvage Project of the Archaeological Heritage of the Ilisu and Carchemish Dam Reservoirs Activities in 2001, Ankara.

Ur, Jason A. (2003)

"CORONA Satellite Photography and Ancient Road Networks: A Northern Mesopotamian Case Study", in: Antiquity 77, I02-II5.

\section{Ur, Jason A. / Hammer, Emily (2009)}

"Pastoral Nomads of the Second and Third Millennia AD on the Upper Tigris River, Turkey: The Hirbemerdon Tepe Survey", in: Journal of Field Archaeology 34, $37-56$.

\section{Wickede, Alwo von (1990)}

Prähistorische Stempelglyptik in Vorderasien, Munich.

Wiggermann, Frans A.M. (2000)

"Agriculture in the Northern Balikh Valley. The Case of Middle Assyrian Tell Sabi Abyad”, in: Remko M. Jas (ed.), Rainfall and Agriculture in Northern Mesopotamia, MOS Studies 3, Leiden, I7I-23I.

Wilkinson, Tony J. / Wilkinson, Eleanor / Ur, Jason A. / Altaweel, Mark (2005)

"Landscape and Settlement in the Neo-Assyrian Empire", in: Bulletin of the American Schools of Oriental Research 340, 23-56. 
